International Journal of Current Advanced Research

ISSN: O: 2319-6475, ISSN: P: 2319 - 6505, Impact Factor: SJIF: 5.995

Available Online at www.journalijcar.org

Volume 6; Issue 4; April 2017; Page No. 3270-3271

DOI: http://dx.doi.org/10.24327/ijcar.2017.3271.0243

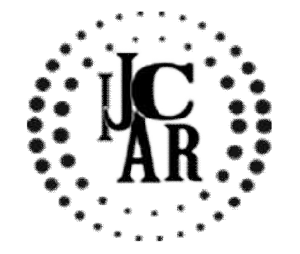

Research Article

\title{
FIRST SURVEY MONOGRAPH OF IMAGE REPORTING BY RADIOLOGIC TECHNOLOGISTS IN SUDAN: DOES ANY INTERESTING/ DESIRE?
}

\section{Awad Elkhadir ${ }^{1}$ and Abdel moneimsaeed Ahmed ${ }^{2}$}

\author{
${ }^{1}$ Department of Diagnostic Radiology, Faculty of Applied Medical Sciences (FAMS), King Abdulaziz University, \\ Jeddah, Saudi Arabia \\ 2Department of Radiologic Technology, College of Applied Medical Sciences, Qassim University
}

\section{A R T I C L E I N F O}

\section{Article History:}

Received $25^{\text {th }}$ January, 2017

Received in revised form $19^{\text {th }}$ February, 2017

Accepted $22^{\text {nd }}$ March, 2017

Published online $28^{\text {th }}$ April, 2017

Key words:

Image reporting, Radiographer, Monograph, Radiologic Technology, DRTSs.

\begin{abstract}
A B S T R A C T
Background: Although Sudan has qualified and veteraned radiographers, image reporting by Diagnostic Radiologic Technology Specialists (DRTSs) is remains unauthorized in this country. Expansion the task of radiographers to have authority of image report in a specific part of the body will reduce the stress on radiologists due to overload work, more reported images and less patient waiting time. Urgent needs to conduct this study to explore desires of DRTSs in Sudan to image reporting

Methodology: A cross-sectional monograph was conducted to know desires of DRTSs in Sudan to image reporting. Questionnaire distributed in August 2014 directly to random of 139 DRTSs.

Results: It was observed that $94.2 \%(n=131 / 139)$ of the participants in Sudan would like to write a report of image.

Conclusion: There are more interesting of image reporting by DRTSs in Sudan.
\end{abstract}

Copyright $(2017$ Awad Elkhadir and Abdel moneimsaeed Ahmed. This is an open access article distributed under the Creative Commons Attribution License, which permits unrestricted use, distribution, and reproduction in any medium, provided the original work is properly cited.

\section{INTRODUCTION}

Diagnostic Radiologic Technology Specialists (DRTSs) in some country called radiographers. Sudan National Council for medical and health professions (NCMHP) classify DRTS who has a bachelor's degree in Diagnostic Radiological Technology (DRT) from a recognized University by NCMHP second specialist. ${ }^{1}$ Despite the fact that many DRTSs have several qualifications in radiography, didn't yet found a clear job description for these new names of classifications. Most DRT programmes in Sudanese universities, offering a 5-4 year BSc Honors degree. In addition, some universities have $\mathrm{MSc}$ and $\mathrm{PhD}$ programmes as well, such as Sudan University of Science and Technology. Unfortunately, there is a huge shortage of radiologists currently because Sudan has just only 102 graduated radiologists from Sudan Medical Specialization Board (SMSB) between (2008-June 2015). ${ }^{2}$ As result of largerpopulation 39,613,217 according to report of United Nations in $2015^{3}$ and also because of the Numbers of radiologists are insufficient. Eventmost of them are found in Khartoum center ${ }^{4}$, there is inadequate services of diagnoses diseases particularly in the areas far away from the Khartoum city center. To overcome such as this problem other countries like Australia and UK recognized the image interpretation by radiographers. ${ }^{5,6,7}$

*Corresponding author: Awad Elkhadir Department of Diagnostic Radiology, Faculty of Applied Medical Sciences (FAMS), King Abdulaziz University, Jeddah, Saudi Arabia
Over the last two decades radiographer abnormality detectionschemes (RADS) such as red dot and last commenting have become widely spread. ${ }^{8,9,10,11}$ The expectation of College of Radiographers (CoR), Health Professionals Council (HPC) and the academic Quality Assurance Agency (QAA) bodies is that on qualification, radiographers will possess image interpretation skills. ${ }^{7,12,13}$ This is first a study aiming to discuss this important issue in the Arab World.

\section{METHODOLOGY}

A cross-sectional study was conducted to know desires of DRTSs in Sudan to image reporting. Questionnaire distributed in August 2014 directly to random group of DRTSs (139). One important closed question required answering with no or yes was asked to see if the participant would like to write a report for the image of a specific part of the body in case of getting proper training in radiographic image reporting or didn't want?Data was analyzed using IBM-SPSS 16.0. Statistical significance was acceptable at $\mathrm{P}$ value $<0.05$.

\section{RESULT AND OBSERVATIONS}

Survey showed statistically significant $(\mathrm{P}$-value $=0.000$; d.f. $=1)$ of DRTSs $94.2 \%(n=131 / 139)$ have a strongly would like to write a report of image, while just $5.8 \%(n=8 / 139)$ didn't have any interesting to get this task (Table 1). 
Table 1 Interesting of DRTSs in image reporting

\begin{tabular}{ccccc}
\hline Answer & Frequency & Percent & P-value & df \\
\hline Yes & 131 & 94.2 & & \\
No & 8 & 5.8 & .000 & 1 \\
Total & 139 & 100.0 & & \\
\hline
\end{tabular}

\section{DISCUSSION}

This study explores that DRSs have quite enough interesting to writing radiographic images reporting in Sudan. Importantly while, the authorization to enable DRTSs to do this task still doesn't found in Sudan, there were several studies showed an important role of radiographers in writing reports such as a recent a longitudinal analysis study in UK by B. Snaith et $a .^{9}$ Where showed an important role of radiographers in writing reports. ${ }^{14}$ DRTSs in Sudan faces several challenges despite, the quite enough qualified who have good reputable abroad, working in a prestigious institutions and they success in examinations of international professional organizations such as Europe and United States. ${ }^{2}$ Image reporting by diagnostic radiologic technologist is remains one of a big challenges in Sudan and also the Middle East. Even though radiographer in developed countries got this authorization more earlier., ${ }^{5,6,7,8,9,10,11,19}$ In UK the quality of radiographer reporting is similar to a consultant radiologist regardless the area of clinical practice. ${ }^{16,17,18}$

\section{CONCLUSION}

Decisive step should be taken to achieve these strongly and reasonable interesting of image reporting by DRTSs in Sudan. Overall Radiography institutions especially in Sudan hence should struggle to be centers not just to information transmission, but of innovation and creative researches to support scientists, researchers, academicians and students in conducting research and working to develop radiography profession.

Expertise, training, improve imaging services and strongly desire to improvement are all necessary to introduce good health services

\section{Acknowledgement}

I would like to thank all my colleagues in Sudan who endeavoured to fill the questionnaires.

\section{References}

1. http://ncmhp.gov.sd/

2. Sudan Medical Specialization Board (SMSB):

3. http://www.smsb.gov.sd/ar/index.php/specialization/20 14-11-19-03-19-54/2014-11-19-03-35-39
4. Royal College of Radiologists. Cancer Taskforce: submission by The Royal College of Radiologists. London: RCR, 2015

5. https://www.rcr.ac.uk/sites/default/files/RCR(15)4_Ca ncerTaskforce.pdf

6. http://41.67.53.40/handle/123456789/3862?show=full

7. College of Radiographers. Medical Image Interpretation \& Clinical Reporting by NonRadiologists: The Role of the Radiographer London: College of Radiographers; 2006.

8. Price R. Radiographer reporting: origins, demise and revival of plain film reporting. Radiography 2001; 7: 105-17.

9. Royal College of Radiologists and Society and College of Radiographers. Team working within clinical imaging: A contemporary view of skills mix. London, UK: Royal College of Radiologists; 2006.

10. Berman L, de Lacey G, Twomey E, Twomey B, Welch, $\mathrm{T}$ and Eban, R. 'Reducing errors in the accident department: a simple method using radiographers', British Medical Journal 1985; 290: 421-2.

11. Brealey S, Scally A, Hahn S, Thomas N, Godfrey C. and Crane S. Accuracy of radiographers red dot or triage of accident and emergency radiographs in clinical practice: a systematic review. Clinical Radiology 2006; 61: 604-15.

12. Snaith B and Hardy M. Radiographer abnormality detection schemes in the trauma environment-An assessment of current practice. Radiography (under review)

13. Hardy $M$ and Snaith B. Radiographer reporting of trauma images: evaluation of practice in the United Kingdom. British Journal of Radiology (under review).

14. http://www.moh.gov.sa/.

15. Woznitza N, Piper K, Burke S, Patel K, Amin S, Grayson $\mathrm{K}$, et al. Adult chest radiograph reporting by radiographers: preliminary data from an in-house audit programme. Radiography 2014; 20:223e9.

16. Brealey S, Scally A, Hahn S, et al. Accuracy of radiographer plain radiograph reporting in clinical practice: a meta-analysis. ClinRadiol 2005; 60: 232e41.

17. Royal College of Radiologists, Society \& College of Radiographers. Team working in clinical imaging. London: Royal College of Radiologists and the Society and College of Radiographers; 2012.

18. Snaith BA. Are Trusts replacing the red dot? British Journal of Radiology UKRC supplement 2004; 46-7.

\section{How to cite this article:}

Awad Elkhadir and Abdel moneimsaeed Ahmed (2017) ' First Survey Monograph Of Image Reporting By Radiologic

Technologists In Sudan: Does Any Interesting/ Desire?', International Journal of Current Advanced Research,

06(04), pp. 3270-3271.DOI: http://dx.doi.org/10.24327/ijcar.2017.3271.0243 